University of Nebraska - Lincoln

DigitalCommons@University of Nebraska - Lincoln

Anthropology Faculty Publications

Anthropology, Department of

$1-2014$

\title{
Movement as a means of social (re)production: Using GIS to measure social integration across urban landscapes
}

Heather Richards-Rissetto

University of Nebraska-Lincoln, richards-rissetto@unl.edu

Kristin Landau

Northwestern University, kvlandau@u.northwestern.edu

Follow this and additional works at: http://digitalcommons.unl.edu/anthropologyfacpub

Part of the Archaeological Anthropology Commons, Digital Humanities Commons, Geographic Information Sciences Commons, Latin American Languages and Societies Commons, and the Urban Studies and Planning Commons

Richards-Rissetto, Heather and Landau, Kristin, "Movement as a means of social (re)production: Using GIS to measure social integration across urban landscapes" (2014). Anthropology Faculty Publications. 65.

http://digitalcommons.unl.edu/anthropologyfacpub/65

This Article is brought to you for free and open access by the Anthropology, Department of at DigitalCommons@University of Nebraska - Lincoln. It has been accepted for inclusion in Anthropology Faculty Publications by an authorized administrator of DigitalCommons@University of Nebraska Lincoln. 


\title{
Movement as a means of social (re)production: Using GIS to measure social integration across urban landscapes
}

\author{
Heather Richards-Rissetto \\ Department of Geography, Middlebury College, Middlebury, VT 05753, USA, and \\ Department of Anthropology, University of New Mexico, Albuquerque, NM 87131, USA; \\ email h.m.richards.rissetto@gmail.com (Corresponding author) \\ Kristin Landau \\ Northwestern University, Evanston, IL 60208, USA; \\ email kvlandau@u.northwestern.edu
}

\begin{abstract}
This paper contributes to the archaeological study of movement in urban environments where built forms and natural features worked together to play a key role in structuring human mobility. We propose an analytical method using least cost analysis in a Geographic Information System (GIS) to empirically measure social integration. The method defines mobility as the potential for pedestrian movement, and identifies locations where people were most likely to walk to or through in a landscape. The calculated mobility data are then employed to identify with whom people were most likely to interact and the degree to which they were socially connected with particular groups of society (social networks), and integrated within society as a whole. The results reveal underlying spatial complexities that in conjunction with other archaeological data can be correlated to social, political, or economic inequality in ancient cities. We apply the method to measure social integration between four socioeconomic groups at the Late Classic (AD 600-900) Maya city of Copán, Honduras.
\end{abstract}

Keywords: Movement, Landscape, Geographic Information Systems (GIS), Least cost analysis (LCA), Ancient Maya, Mobility maps, Social inequality

\section{Introduction}

Although archaeologists have long considered where ancient people built houses, ritual structures, and civic-ceremonial centers, they have not often considered movement among these features, particularly within cities where built forms and the natural landscape together guided movement. Recent years have seen new archaeological thinking on movement, mobility, and circulation (e.g. AAA, 2010; TOPOI, 2011; Snead et al., 2009; White and Surface-Evans, 2012), including several methods using Geographic Information Systems (GIS) (e.g. Llobera et al., 2011; Taliaferro et al., 2010). The following summarizes key insights underlying many of these approaches, and presents one empirical way to measure social integration in an urban setting.

The spatial organization of settlements and landscapes reflected and shaped ancient life (De Certeau, 1984; Giddens, 1984; Goffman, 1983; Jakobson, 1980; Morgan, 1984; Parmentier, 1987; Peirce, 1966; Silverstein, 1976). People often locate themselves and organize their surroundings to facilitate or restrict access, channel movement, and send visual cues to influence interaction (e.g. Ashmore and Knapp, 1999; Doyle et al.,
2012; Hillier and Hanson, 1984; Lawrence and Low, 1990; Llobera, 2000; Rapoport, 1990; Smith, 2011b). Features of the natural landscape, such as topography or hydrology (Anaya Hernandez, 2001b; Rahn, 2005), as well as the human-made built environment, such as houses or streets, affect how individuals and groups move within a place.

We define mobility as the potential for movement across a landscape (Inomata, 2004:179). Consideration of potential, rather than actual, paths of movement allows us to model spatial relations on the scale of neighborhoods, cities, or regions and infer the kind and intensity of social relations between members of society. We use GIS (ESRI ArcGIS 10.0 and 9.3) to compute the cost of movement across a landscape, and derive least cost paths from one location to others. We argue that the average value (i.e. travel time) of these paths is a useful proxy for estimating movement between locations. People are more likely to travel to and interact with people living at places they can more easily, or quickly, reach, because such places are more accessible. Therefore, we assess the social integration of an urban center by calculating how different groups of people were able to move and interact with others within it. 


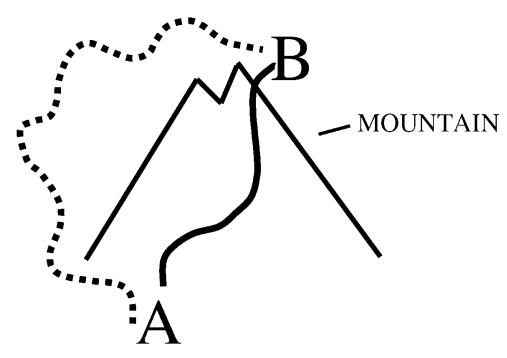

Figure 1. Least cost analysis: to travel from A to B, individuals are likely to take the longer path (dotted) than the shorter path (solid) if walking along the longer path is more energetically conservative or time efficient.

\section{Studying social (re)production through mobility}

Rodrigue et al. (2009) define accessibility as the measure of the capacity of a location to be reached (attractiveness), or the capacity to reach different locations (emissiveness). Locations of high accessibility are more easily reached, and are likely to have more people travel to or through them than locations of low accessibility. Such locations are also more connected to, or integrated with, a system as a whole (e.g. a city), or sub-parts of the system (e.g. neighborhoods). Research using space syntax-an approach that measures how the spatial structure of cities influences movement - has established a one-to-one relationship between accessibility and social integration: if a place is easily accessible, it is also highly integrated with the citywide economy and social life (Hillier, 1996; Hillier et al., 1993).

Therefore, the amount of movement to, through, or from a place strongly correlates with "integration" in urban systems. Integration values measure how easily a place can reach or be reached from all other locations in the system (Bafna, 2003; Hillier, 1996:160; Ratti, 2004:489). While most space syntax approaches that calculate integration values (particularly in archaeology) are based on axial maps (e.g. Fisher, 2009; Parmington, 2011; Stuardo, 2003), scholars are developing alternative approaches with GIS (e.g. Jiang and Claramunt, 2002; Jiang and Gimblett, 2002; Ratti, 2005; Shelton, 2012). For example, the cost-of-passage function calculates the accumulated cost of moving within a street network using an Urban Digital Elevation Model - a raster surface that stores heights of the urban surface (Ratti, 2004, 2005; Ratti and Baker, 2003). Urban landscapes with clustered housing and informal settlement patterns such as sites throughout the Basin of Mexico, Singhalese and Khmer settlements, or Classic Maya cities, tend to be strongly influenced by environmental features and agrarian practices (Fletcher, 2009; Smith, 2010; Stark and Ossa, 2007). Therefore, it is necessary to incorporate cost parameters, such as topography, hydrology, and land cover that are not traditionally considered in urban analyses of movement. To account for these factors, we propose a least cost analysis (LCA) approach.

LCA subscribes to Zipf's Principle of Least Effort (1949), which postulates that people tend to economize their behavior by following paths that take the least amount of energy or time to traverse (White and Surface-Evans, 2012) (Figure 1). ${ }^{1}$ In GIS, least cost path analysis identifies the route(s) with the lowest accumulated cost(s) based on user-defined cost parameters. The average value of all least cost paths to or from a location corresponds to what we call an integration value. Locations with higher average pathcosts are (1) more costly to reach, (2) less likely to have people travel to or through them, and (3) less integrated than locations with lower average pathcosts. These average least cost path values serve as a proxy to measure the integration or segregation of groups of people across urban landscapes.
Some might consider a least cost approach overly econometric, or based too strongly on the assumption that humans act in energetically efficient ways. While we agree that it is unlikely that ancient people planned cities solely according to energy-reduction principles (in the ancient Maya area, e.g. Ashmore, 1991; Aveni, 2001; Broda, 1982; Mathews and Garber, 2004), we contend that in the course of daily routines all populations would have, to some degree, optimized behavior (Murrieta-Flores, 2010). Additionally, social interaction, production, and reproduction can only occur at discrete points of time-geography, so while the importance of time across human societies is debatable, time is a universally constitutive dimension of movement between places (Carlstein, 1982; Pred, 1981). The factors that affect movement between points in time-geography (e.g. topography, hydrology), together with a person's sociocultural background shape mobility patterns that create spatial expressions of difference, or "geographies of difference," that structure and reflect potential interactions, relationships, and social (in)equalities (Harvey, 1996; Kosiba and Bauer, 2012).

\section{Case study: Late Classic (AD 600-900) Copán, Honduras}

The city of Copán, located in today's western Honduras, was a major center of artistic, scientific, and political achievement for the Maya during the Late Classic period (AD 600900). Ancient Copán residents witnessed simultaneous florescence and sociopolitical distress (Fash, 2001): population peaked at 22,000 (Webster, 2005), construction of monumental architecture increased, and political influence extended to over $250 \mathrm{~km}^{2}$ (Andrews and Fash, 2005), yet a major ruler was decapitated by a vassal center. Archaeological settlement surveys have shown that most if not all architecture still visible on the surface dates to the Late Classic period (Figure 2). Half of all settlement is concentrated in the urban core, with additional clustered structures located on the surrounding foothills and intermountain pockets. The urban core-a three square kilometer area at the center of the city (Maca, 2002; Webster, 1985) and focus of our case study - contained at least 235 architectural groups comprising more than 1800 structures and housing between 10,000 and 12,000 people (Fash and Long, 1983; Webster, 2005). Due in part to the absence of a formal street network, researchers have focused on specific architectural forms, like rural households, royal tombs, and elite residences (e.g. Andrews and Fash, 2005; Bell et al., 2004; Fash, 2001; Gonlin, 1993; Webster, 1989; Webster and Gonlin, 1988). Consequently, we know surprisingly little about how people might have physically interacted, patterns of movement, social connectivity between different socioeconomic classes, and social inequality. The same can be said for many other major Late Classic sites in the Maya area.

\subsection{Classic Maya social organization: Expectations for social integration}

Based on excavations and the latest hieroglyphic decipherments, researchers have established models of Classic Maya political hierarchy. While scholars generally agree that the royal family and other elite governed a society comprising priests, scribes, artisans, farmers, merchants, warriors, servants, and slaves (e.g. Houston and Inomata, 2009; Inomata and Houston, 2001; Rice, 2004; Coe and van Stone, 2005; Kintz, 1983; Martin and Grube, 2008; Viel, 1999), debates ensue on whether Maya society was two-tier (elite/commoner) vs. three-tier (emerging middle-class) (Chase and Chase, 1992), segmentary or centralized (Fox et al., 1996; Iannone, 2002; Sanders and Webster, 1988), and hierarchical or heterarchical (Gillespie, 2000; Joyce and Gillespie, 2000; Potter and 


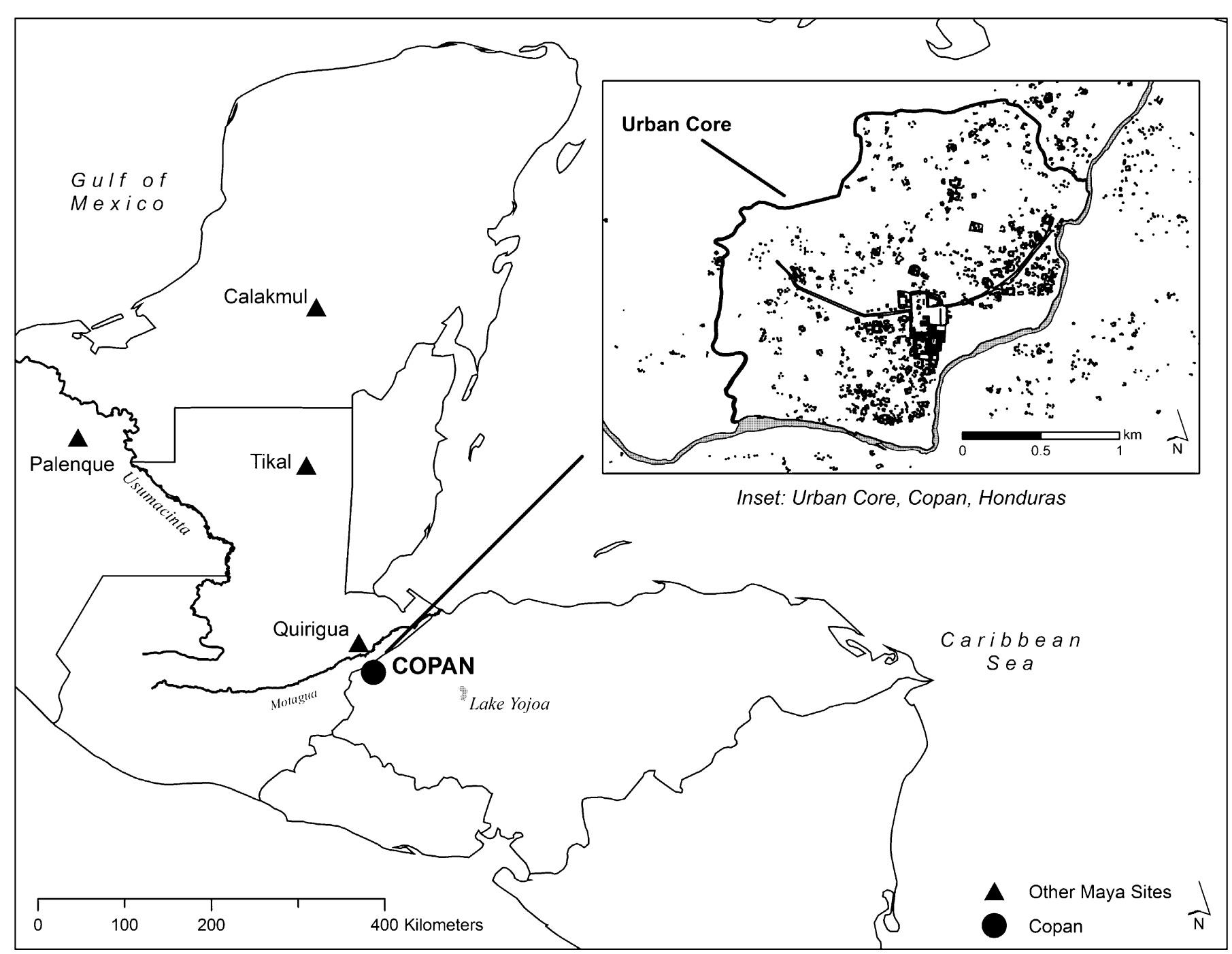

Figure 2. Map of Eastern Mesoamerica. Inset-urban core, Copán, Honduras.

King, 1995; Scarborough et al., 2003; Watanabe, 2004). While regional and temporal variation catalyze these debates, archaeologists have had some success correlating architecture to social organization. Typologies based on building and plaza form, composition, size, and complexity relate to the function(s) (e.g. administrative, ritual, domestic) and socioeconomic status (e.g. royal, elite, non-elite, rural) of occupants (Becker, 1971; Kintz, 1983; Tourtellot, 2004). At Palenque, Mexico, as people entered public spaces they encountered imagery promoting dynastic authority, whereas those who entered restricted spaces witnessed the king in a role subordinate to gods, giving us an insider's perspective to city-level sociopolitical relationships (Parmington, 2011).

At Copán, researchers developed a typology that classifies architectural groups (discrete clusters of individual buildings) into five site types (Fash, 1983; Leventhal, 1979; Willey and Leventhal, 1979). The Harvard Site Typology equates mound size and quantity, and the organizational complexity of structures and associated plazas to socioeconomic status. The types range from non-elite households (types 1 and 2) to elite residences (types 3 and 4) to the royal acropolis (type 5) (Table 1). While only a preliminary model-and one based primarily on physical size-we use the typology as a starting point to select social groups across the Copán landscape based on socioeconomic status.

We build on recent LCA studies that identify connections among movement, settlement patterns, and political hierarchy across landscapes (Anaya Hernandez, 2001a, 2001b, 2006; Murrieta-Flores, 2010, 2012; Rahn, 2005). Our work is unique in that we focus on the relationship among spatial organization, mobility, and social inequality at the urban scale. We relate social inequality to social integration, and access to elite or state-sponsored events. Given the close relationship between spatial order and mobility, we expect to identify mobility patterns that reflect Copán's social hierarchy. That is, we expect that average travel times to and from elite groups (types 3 and 4 ) to be faster than to and from non-elite groups (types 1 and 2). If these expectations are met, then it can be argued that elites resided in accessible

Table 1. Copán typology (from Willey and Leventhal, 1979, pp. 82-83).

\begin{tabular}{|c|c|c|c|c|c|c|}
\hline Type & $\begin{array}{c}\text { \# of } \\
\text { mounds }\end{array}$ & $\begin{array}{l}\text { \# of } \\
\text { plaza }\end{array}$ & $\begin{array}{l}\text { Mound } \\
\text { as height } \\
(\mathrm{m})\end{array}$ & Construction & $\begin{array}{l}\text { Total \# } \\
\text { (urban } \\
\text { core) }\end{array}$ & $\begin{array}{r}\text { Total } \\
\text { \# in } \\
\text { sample }\end{array}$ \\
\hline 1 & $3-5$ & $0-1$ & $0.25-1.25$ & $\begin{array}{l}\text { Earth fill, undressed } \\
\text { stone rubble }\end{array}$ & 134 & 20 \\
\hline 2 & $6-8$ & $1-2$ & $2.50-3.00$ & $\begin{array}{l}\text { Mostly undressed, } \\
\text { but some dressed } \\
\text { surface stone }\end{array}$ & 68 & 13 \\
\hline 3 & $6-8$ & $1-2$ & $3.00-4.75$ & $\begin{array}{l}\text { Much more dressed } \\
\text { stone }\end{array}$ & 20 & 9 \\
\hline 4 & $8+$ & $2+$ & $4.75-10$ & $\begin{array}{l}\text { Large stones, rough and } \\
\text { dressed, vault stones }\end{array}$ & 13 & 7 \\
\hline
\end{tabular}




\begin{abstract}
E (Emissiveness)

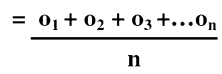

A (Attractiveness)

$=\underline{b_{1}+b_{2}+b_{3}+\ldots b_{n}}$

I (Integration value)

$=\underline{\left(o_{1}+o_{2}+o_{3}+\ldots o_{n}\right)_{+}\left(b_{1}+b_{2}+b_{3}+\ldots b_{n}\right)}$

$\mathbf{n} \div \mathbf{2}$

$\mathrm{o}=$ travel time out (derived from individual least-cost paths from source to destinations) $\mathrm{b}=$ travel time back (derived from individual least-cost paths from destinations to source) $\mathrm{n}=$ number of destinations
\end{abstract}

Figure 3. Formulas for calculating integration values, emissiveness and attractiveness.

locations and/or the accessibility of elite sites increased over time, while the opposite would be true of non-elites. Our expectations do not deny bottom-up community organization and local control of ritual, agricultural, or other activities (Isendahl and Smith, 2013); rather our analysis is of the urban core, and in fact the method could be applied to other analytical scales or used to identify intermediate zones (Arnauld et al., 2012). In terms of broad social (in)equality, large differences in travel cost between different places suggests that settlement across the urban landscape fostered inequality; vice versa, small differences in travel cost between different places might imply greater equality between residents.

\section{Methodology}

This article presents revisions to a least cost analysis (LCA) method to measure social integration originally proposed by Richards-Rissetto (2010 \& 2012). The method measures the potential accessibility of architectural complexes in urban landscapes that exhibit informal settlement patterns using raster data (comprising valued pixels) to calculate accessibility over a contiguous surface rather than a vector-based topological network (e.g. space syntax) (see Richards-Rissetto, 2012 for comparison with space syntax). Using mobility patterns as a proxy measure for potential accessibility, we acquire data on (1) degree of social integration, i.e. are certain groups more or less integrated or segregated from society as a whole, and (2) social connectivity, i.e. who is likely to interact with whom. These data inform understandings of social inequality because they provide information about who might have greater access to social, economic, or political opportunities. Our recent work has modified the original method in two ways: (1) arbitrary units (based on an ordinal scale offering a relative comparison of costs) have been converted to time units (seconds/meter), and (2) both attractiveness and emissiveness are measured (the original measured only emissiveness). Emissiveness and attractiveness provide information on access to resources and opportunities, channeling movement and visual messages that relate to social control and political and economic relations.

The method we present differs from typical least cost path analyses. Most archaeological applications using least cost paths seek to identify actual travel routes or corridors (Bell and Lock, 2000; Kantner, 1997); however, it can be difficult to identify ancient paths due to resolution and quality of topographic data, landscape changes over time, and different least cost computational algorithms depending on the software (but see Harris, 2000; Herzog and Posluschny, 2008). Therefore, our objective is not to identify actual travel routes, but to calculate average travel time to and from specific locations as a proxy for the degree and nature of social interaction. To do this, we calculate integration values using a least cost adjusted-Shimbel index. While the Shimbel index calculates the minimum number of paths necessary to connect one location

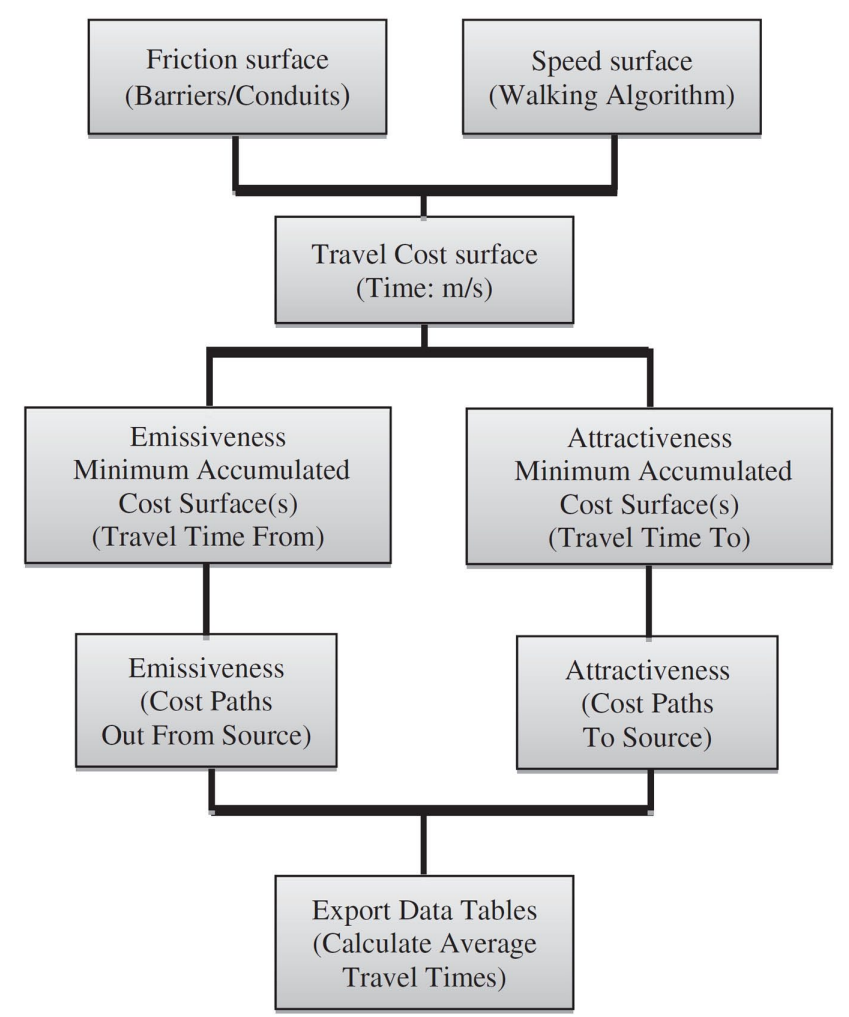

Figure 4. Diagrams of the six-step process and inputs of least cost analysis.

with all other locations in a network, the least cost adjustedShimbel index calculates the average least cost of paths to or from a source point to all potential destinations in a network (Rodrigue et al., 2009). (Figure 3 presents the formulas applied in this study.) Using average least cost also normalizes the data, permitting a comparison of costs between different sub-groups with a different number of source or destination points, a common scenario in archaeology and exemplified below. Another advantage of this method is its utility for comparative analysis across multiple spatial scales, including individual architectural groups, neighborhoods, or whole cities, and between different temporal periods, for example the Early and Late Classic at Copán.

In the case study, we apply this least cost method to four site types from Copán's urban core to derive quantitative data on mobility. We use these data to generate "mobility maps" that show patterns of potential movements for different groups based on average travel time from one place to another. Mobility maps help us to investigate (1) degrees of social integration for different socioeconomic groups, (2) connectivity between socioeconomic groups, and (3) social (in)equality as defined by differential access to economic, social, or political opportunities. To select a representative sample of type 1-4 sites, we employed a stratified random sampling technique. Our sample consists of 49 architectural groups (arguably, households), and represents about $21 \%$ of urban core sites (Table 1 ).

\subsection{Procedure Steps ${ }^{2}$ (Figure 4)}

\subsubsection{Step 1: Friction surface}

The first step is to create a friction surface to represent the difficulty (as a percent of total cost) to cross a single cell (pixel). The friction surface incorporates conduits (e.g. roads) and barriers (e.g. buildings or slope greater than $\left.\mathrm{x}^{\circ}\right)$, combining features of the natural and cultural landscapes. For

2. To automate the process, we developed a python script (modified from Sherrill et al., 2010). The script runs in ArcGIS 9.3 and 10. 

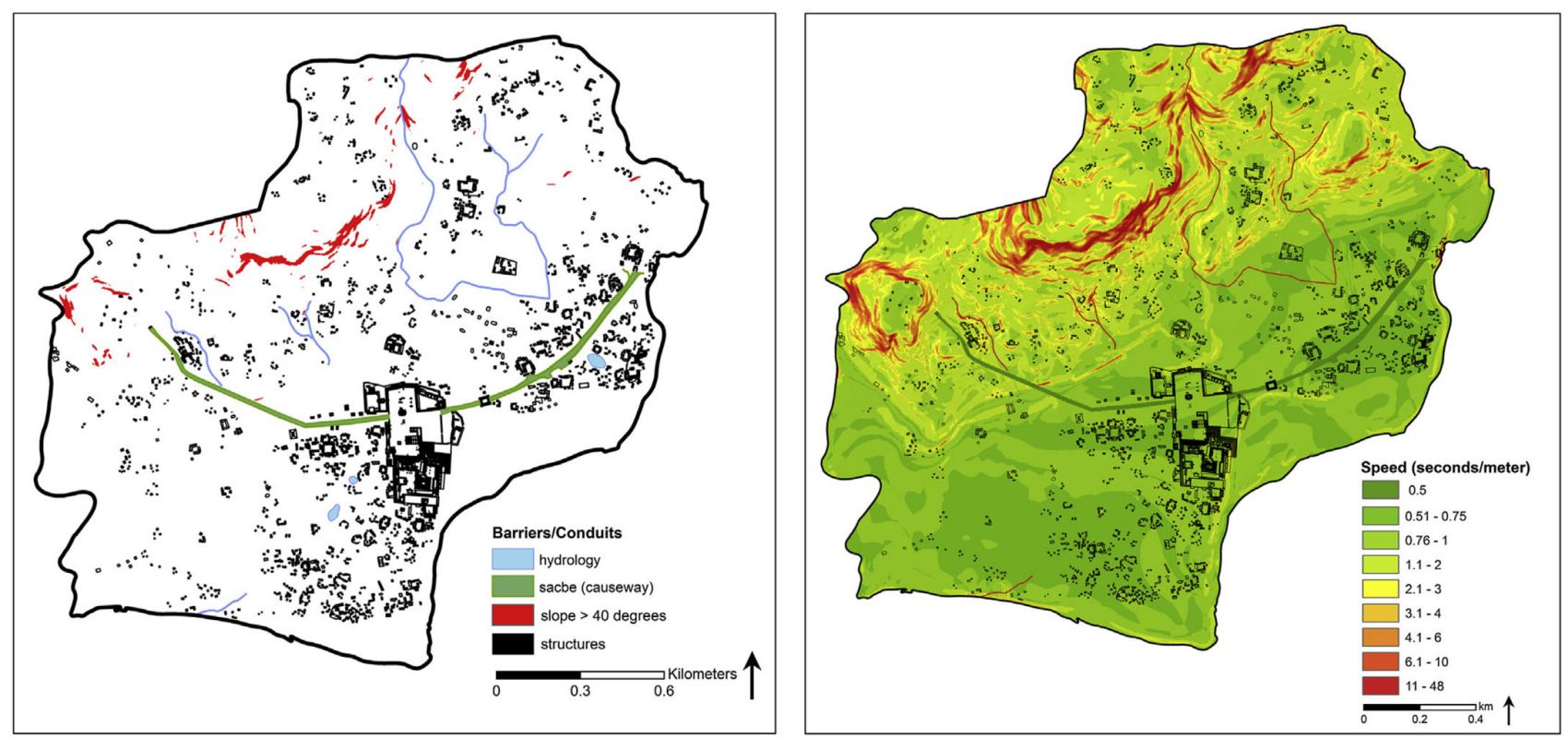

Figure 5. Friction surface-represents the difficulty to cross barriers and conduits (left); Speed surface-represents travel speed across a cell excluding barriers/conduits (right).

the case study, structures, reservoirs, and areas with a slope greater than $40^{\circ}$ were assigned as complete barriers. ${ }^{3}$ Quebradas (stream cuts) were partial barriers and the cost of movement was weighted by a factor of 1.8, preventing travel within quebradas yet permitting movement across them. While we do not account for seasonal variation (e.g. intermittent quebradas or vegetation cycles) such differences could easily be incorporated into the analysis. We considered Copán's two sacbeob (causeways) as conduits (e.g. Chase and Chase, 2001). To decrease travel time along them, we weighted the cost of movement by a factor of 0.7. We employed Map Algebra to integrate these weighted variables into a single raster surface, i.e. the friction surface (Figure 5: left).

\subsubsection{Step 2: Speed surface}

The second step is to create a speed surface that represents how fast one can travel (in seconds per meter) across a single cell. Travel speed is derived from inputting slope (degrees) into a walking algorithm. We generated the slope surface for Copán from the $2 \mathrm{~m}$ Digital Terrain Model Richards-Rissetto digitized from the Proyecto Arqueológico Copán I (PAC I) survey maps (Fash and Long, 1983), and inputted it into Tobler's hiking function (Figure 6) to generate a speed surface in kilometers per hour (Tobler, 1993); however, other algorithms can replace Tobler's (see Pandolf et al., 1977; Van Leusen, 2000). ${ }^{4}$ Using the raster calculator, the speed surface was converted to meters per second (Figure 5: right). The speed surface accounts for the effect of slope on movement, but not barriers or conduits, as performed in the next step.

\subsubsection{Step 3: Travel cost surface}

The third step is to generate a travel cost surface that represents total time required to move from one cell to another cell, accounting for conduits and barriers. This surface is generated by multiplying the friction surface (step 1) and the speed surface (step 2) into a single raster surface. Travel cost is a function of three general categories (conduits, barriers, and slope) that researchers can tailor to specific applications. For Copán, travel cost is a function of four factors: (1) sacbeob speed, (2) slope speed, (3) complete barriers (architecture and slope $>40^{\circ}$ ), and (4) partial barriers (quebradas) (Figure 7). While the travel cost surface incorporates conduits and barriers to movement, we acknowledge that it remains a simplification or abstraction of the real world that could be improved upon in the future. (Natural and cultural factors such as such as terrain type (e.g. bog, sand), land cover (e.g. deciduous, grassland), compelling features, avoidance areas, and other social phenomena (e.g. sacred places, social memories, trade, or alliances) (Munn, 1996; Stanton and Magnoni, 2008) could all be incorporated.)

\subsubsection{Step 4a/4b: Minimum accumulated cost surfaces (emissive- ness $\mathcal{E}$ attractiveness)}

The fourth step is to create travel-time surfaces, which represent the minimum accumulated cost to move from a start location to a destination or set of destinations (Llobera et al., 2011; Van Leusen, 2000). In some urban areas topography played a major role in structuring human movement (such as the highlands and southern lowlands of the Maya area): the cost to arrive at a particular place (attractiveness) will not be the same as the cost to leave a particular place (emissiveness). As Copán exemplifies such a situation, we created two time surfaces (travel time out and travel time back) for every source location. The time surfaces use anisotropic modeling to take into account the influence of slope direction (i.e. upslope or downslope) on movement (Kantner, 2004; Wheatley and Gillings, 2002).

The emissiveness and attractiveness surfaces were generated using the PathDistance tool to account for actual surface distance (bumpy vs. flat surface) and for direction dependent costs (i.e. upslope vs. downslope). The inputs were: (1) source site (one of our randomly chosen architectural groups), (2) the travel cost surface, and (3) a linear vertical graph (based on slope). We selected a linear vertical factor, which decreases speed for uphill travel and increases speed for downhill travel; other vertical graphs (e.g. inverse linear) can be used. In total, we generated 98 travel time surfaces: an emissiveness and an attractiveness surface for each of the 49 architectural groups considered in our case study.

3. Studies indicate that maximum slope for pedestrian movement varies based on factors such as age, activity, load, perception, and slope direction (Kinsella-Shaw et al., 1992; Proffitt et al., 1995).

4. Multiple formulas exist for converting cost to time traveled, but Tobler's hiking function has been found to be the most reasonable estimator for travel time in rough terrain (Kantner, 2004:327). 


\title{
$\mathrm{W}=(6 * \operatorname{Exp}(-3.5 *(\operatorname{Abs}(\operatorname{Tan}(($ ("slope") $) /(57.29578))+.05))))$
}

\author{
$\mathrm{W}=$ walking velocity $(\mathrm{km} / \mathrm{hr})$ \\ Exp $=e$ (base of natural logarithms) \\ $-3.5=$ constant derived from an optimum travel speed on a $-3.5^{\circ}$ downslope (following Imhof 1950) \\ Tan is in radians (calculated by dividing slope by 1 radian or $57.29578^{\circ}$ ) \\ Slope $=$ slope in degrees $($ input $=$ raster file $)$ \\ * Using Tobler's hiking formula velocity on flat terrain is $5 \mathrm{~km} / \mathrm{hr}$; however, speed on flat ground can be \\ changed in python script to reflect age, gender, etc.
}

Figure 6. Tobler's hiking formula.

\subsubsection{Step 5a/5b: Generate least cost paths - (emissiveness) $\mathcal{E}$ attractiveness}

The fifth step is to run cost paths, which signify the minimum travel time required to reach or return to a location. Using the emissiveness surfaces created in Step 4, we generated least cost paths from each source site to all destinations $(n=235)$ based on site type (e.g. source site to type 1 sites, then to type 2 sites, etc.). Using the attractiveness surfaces from Step 4, we generated least cost paths back from each destination based on site type to each source site (see Figure 8 for one illustration of paths and travel times).

Because the least cost paths were generated from the travel-time surfaces, travel time (in seconds) along each path was automatically calculated. The raster paths were converted to shapefiles with attribute tables that stored travel times, and then exported to calculate average travel times for (1) individual architectural groups and (2) site types 1-4.

\subsubsection{Step 6a/6b/6c: Calculate emissiveness, attractiveness $\mathcal{E}$ inte- gration values}

The final step is to export the data (travel times out and back) for each of the source sites, and aggregate them based on significant variables (e.g. site type, neighborhood affiliation, or proximity to particular resources) for the study area under investigation. We generated data sub-sets (as least cost paths in ArcGIS) according to site types 1-4 for each source site. Then we exported these data sub-sets to Microsoft Excel, for a total of 392 tables. ${ }^{5}$ Finally, we aggregated the data from these tables according to (6a) emissiveness (travel time out), (6b) attractiveness (travel time back), and (6c) integration values (average of travel time out and back).

6a and b: Emissiveness and Attractiveness: For each source site, we exported four data tables with emissiveness values (converted to minutes; 196 tables), and with attractiveness values (converted to minutes, 196 tables) for a total of 392 tables. The emissiveness tables recorded travel costs from architectural groups (source sites) to destinations classified according to site type, and the attractiveness tables vice versa. Data from these 392 tables were aggregated into eight tables, one per site type (1-4) for each emissiveness and attractiveness, in order to calculate average travel times from all source sites to each of Copán's four site types.

6c: Integration values: To calculate average travel times to and from site types (1-4), we aggregated the emissiveness and attractiveness data to create a total of four tables.

\section{Results}

\subsection{Summary statistics}

Table 2 presents aggregate travel times based on site type. The emissiveness data indicate that travel times from Type 4 (highest-order elite) sites to other sites were the fastest $(t=12.82)$. In contrast, travel from Type 1 (lowest-order non-elite) sites took the longest $(t=15.56)$. Travel times from type 2 and 3 sites were similar $(t=14.12$ and $t=14.07$, respectively). The attractiveness data indicate that travel times to Type 4 (highest-order elite) sites to other sites were the fastest $(t=12.56)$. In contrast, travel to Type 1 (lowest-order non-elite) sites took the longest $(t=15.88)$. Travel times to type 2 and 3 sites were similar $(t=14.34$ and $t=14.19$, respectively). Averaging emissiveness and attractiveness times to generate integration values indicates that travel times to and from type 4 (highest-order elite) sites to other sites were the fastest $(t=12.70)$. In contrast, travel to and from type 1 (lowest-order non-elite) sites took the longest $(t=15.72)$. Travel times to type 2 and 3 sites were simi$\operatorname{lar}(t=14.23$ and $t=14.14$, respectively). The emissiveness and attractiveness data as well as the integration values corroborate each other.

\subsection{Mobility patterns}

From the summary statistics, we generated mobility maps to compare the mobility patterns of Copán's four socioeconomic groups, which show a correspondence between mobility and socioeconomic status. Generally, the mobility patterns reflect social order as hypothesized by the Harvard Site Typology (i.e. type 4 sites at most accessible locations and type 1 sites at least accessible locations). However, contrary to our expectations, type 3 and 4 "elite" sites did not have similar travel times, nor did type 1 and 2 "non-elite" sites. Instead, travel times for type 2 and type 3 sites were almost identical (Figure 9). These results confirm Richards-Rissetto's earlier work (2010), suggesting that the distinction between type 2 and 3 sites should be reevaluated. ${ }^{6}$ Subsequent test excavations at type 2 sites recovered "elite" architecture and artifacts at presumed nonelite sites (Landau, 2013; Webster et al., 2000). These archaeological findings suggest that mobility patterns indeed reflect and influence social structure, perhaps more than architectural group size or organizational complexity. The least cost approach aligns well with excavation results, and both undermine a one-to-one correlation between size, complexity, and status for ancient Maya architecture and planning.

\section{Discussion}

\subsection{Social integration}

At Copán, integration values from the urban core indicate that residents at non-elite type 1 sites were the most segregated group, and residents at elite type 4 sites were the most integrated group (Table 2; Figure 9). The low social status of residents occupying type 1 sites was underscored by their spatial placement in more segregated areas. While residents of type 1 sites may have had easier access to agricultural fields or local shrines, they had to spend more time to witness major ritual events, pay tribute at the civic-ceremonial core or elite sites, or acquire seasonal water rations from the city's 


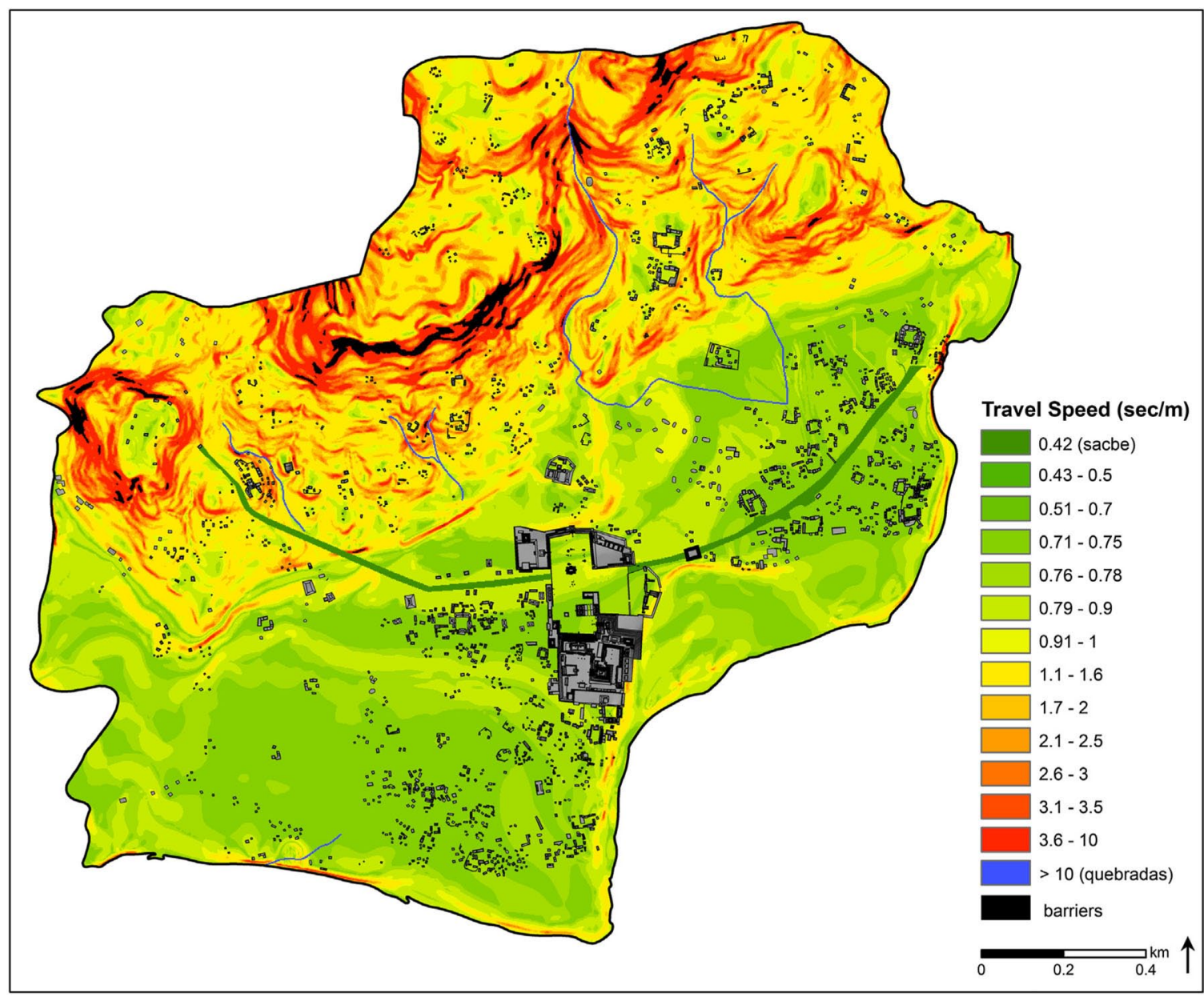

Figure 7. Travel cost surface-represents total time to move from one cell to another cell (includes barriers/conduits).

reservoirs (Davis-Salazar, 2003; Fash, 2005). Conversely, the elites who resided at type 4 sites could more easily attend events at the civic-ceremonial core or routinely interact with other urban core dwellers, particularly Copán's rulers, whose royal temples and residence they could more quickly reach (emissiveness) (Richards-Rissetto, 2010, 2012). The placement of elite complexes at accessible, highly integrated locations suggests that to attend state-sponsored events or carry out
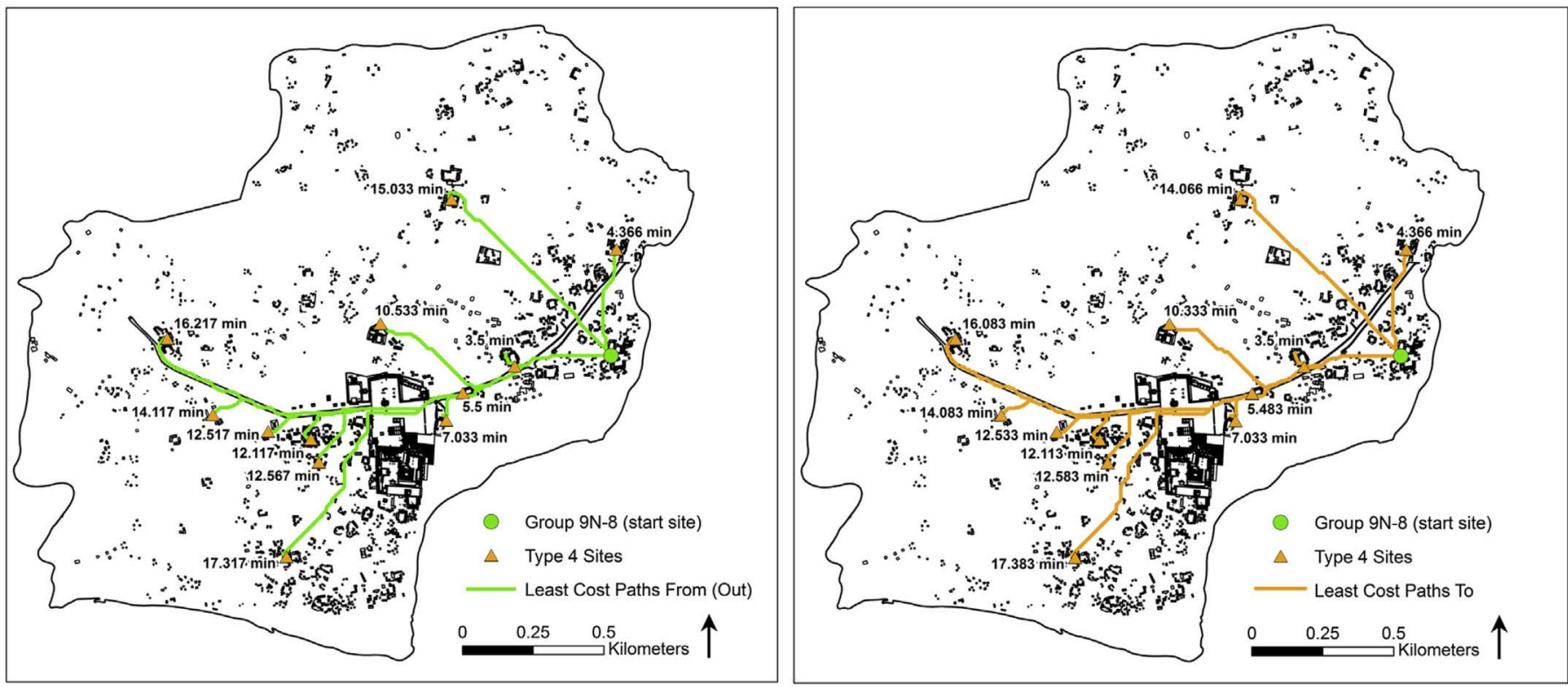

Figure 8. Emissiveness map (left) showing cost paths from Group $9 \mathrm{~N}-8$ (an example start site) out, and attractiveness map (right) showing cost paths from destinations back to Group $9 \mathrm{~N}-8$. 
Table 2. Mobility data (travel times) for Copán's urban core sites (bold indicates similar values of type 2 and 3 sites).

\begin{tabular}{lcccc}
\hline $\begin{array}{l}\text { Source } \\
\text { Site Type }\end{array}$ & $\begin{array}{c}\text { Emissiveness } \\
\text { (Travel Time From) }\end{array}$ & $\begin{array}{c}\text { Attractiveness } \\
\text { (Travel Time To) }\end{array}$ & $\begin{array}{c}\text { Integration Value } \\
\text { (Avg. Travel Time) }\end{array}$ & \\
\hline Type 1 & 15.56 & 15.88 & 15.72 & Segregated \\
Type 2 & 14.12 & 14.34 & 14.23 & \\
Type 3 & 14.07 & 14.19 & 14.14 & \\
Type 4 & 12.82 & 12.56 & 12.70 & $\downarrow$ Integrated \\
\hline
\end{tabular}

economic exchanges in the civic-ceremonial group, lower status people moved past elite households adorned with ornate sculpture atop high platforms that conspicuously displayed a message of high status, wealth, and prestige (attractiveness) (Dahlin et al., 2007; Shaw, 2012; Trigger, 1990). Figure 10 illustrates how travel to type 1 sites requires passing by type 4 sites, while the opposite is not necessarily true. Through daily routines and bodily movement the elite may have created the means to forge and reinforce economic ties, social cohesion, and political support (Rapoport, 1990; Smith, 2007).

\subsection{Social connectivity}

While the integration values indicate that type 1 residents lived at segregated locations and type 4 residents lived at integrated locations, we also analyze the disaggregated (emissiveness and attractiveness) data to investigate which socioeconomic groups were more likely to interact with other groups of the same type. Table 3 lists round-trip times between specific site types. These data offer insight into intragroup and intergroup relationships, by indicating a pattern of hierarchically structured relationships - elite living at type 4 sites were able to establish strong social connections with members from their own socioeconomic class, while simultaneously segregating members of lower classes from each other. Travel between type 4 sites was, on average, seven minutes faster than travel from elite type 4 sites to non-elite type 1 sites, indicating that residents of type 4 elite sites were more strongly connected to members of their own social class then a lower class. In contrast, intragroup travel between lower status residents took much longer; travel between type 1 sites took almost six minutes longer than travel from type 1 to type 4 sites. For Copán's $3 \mathrm{~km}^{2}$ urban core, this difference equates to ca. $25 \%$ longer travel times that may reflect intentional intragroup segregation and channeling of lower status residents to or past type 4 complexes to establish and reinforce social groups on an economic and/or political basis.

\section{Conclusions: Movement as a means of social re(production)}

Movement is a cultural mechanism (or practice) that structures the flow of information and enables interactions that produce and reproduce social networks (Bourdieu, 1977; Giddens, 1984; Murrieta-Flores, 2010; Rapoport, 1990). Because mobility patterns reflect the potential for face-to-face interaction, they can be read as social networks, and thus provide information on social integration, social connectivity, and finally, social inequality. This paper presents a method to empirically measure social integration based on mobility patterns.

Within Copán's urban core, our preliminary results show that the potential for movement across the landscape correlates with social status. Our least cost mobility analysis revealed relationships between spatial and social inequalities that help refine prior models of socioeconomic hierarchy, especially in regard to "middle-level" type 2 and 3 settlement. On one hand, significant difference in mobility between type 4 and 1 sites indicates a hierarchical socioeconomic structure; on the other hand, the lack of difference between type 2 and 3 sites seems to reveal internal variation-possibly masked by hierarchical thinking-and points to presence of more fluid or heterarchical categories. In other words, consideration of mobility among architectural groups suggests heterarchical relationships within an overall hierarchy, as has been proposed for other sites in the Maya area (e.g. Potter and King, 1995; Tourtellot et al., 2003).

For the ancient Maya, mobility analysis reveals a more complex picture of social organization than traditional size-ranked site typologies. Perhaps consideration of movement across the built and natural landscape-physical structures and the "empty" space between them-will be useful for understanding the social and political organization of ancient Maya cities, a topic where no significant agreement exists (Chase and Chase, 2004; Watanabe, 2004). Future work will statistically evaluate the mobility data, and analyze and compare features at selected architectural groups to generate more refined hypotheses for

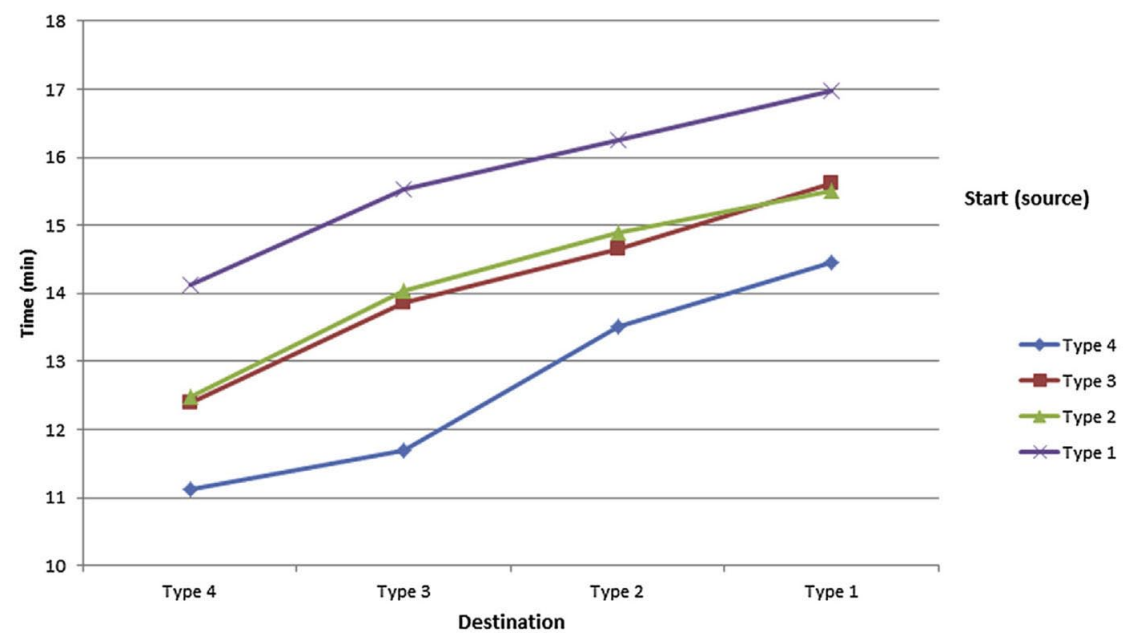

Figure 9. Graph depicting mobility patterns of Copán's site types. 

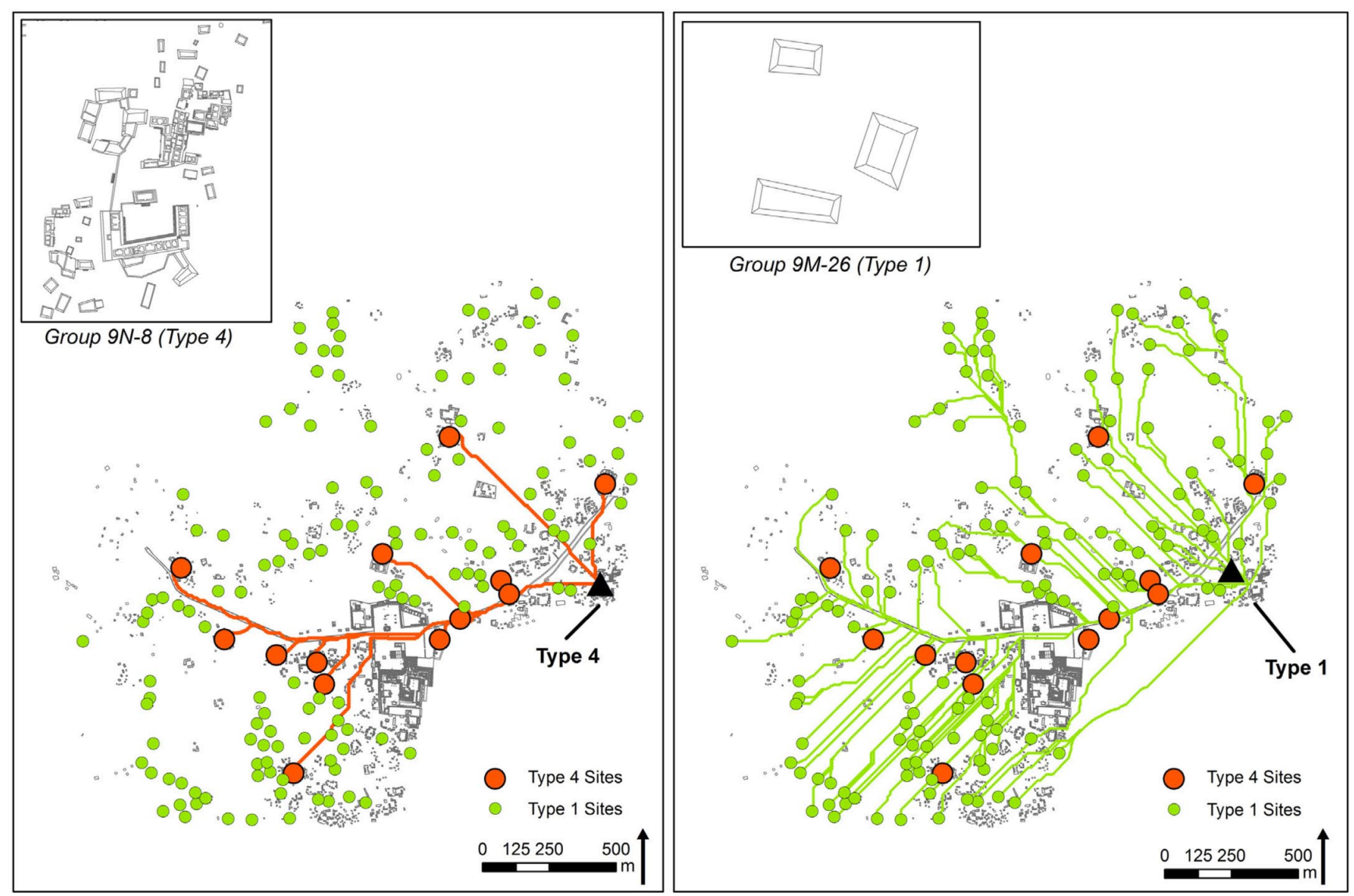

Figure 10. Comparison of travel between Type 1 and Type 4 sites in Copán's urban core.

subsequent archaeological investigation. As well, further investigation of physical and/or cultural factors that influence movement for the ancient Maya specifically, or any cultural group generally (e.g. Fisher, 2009), will add much to the accurate calculation of mobility and social integration.

Our methodology can be applied to social categories other than socioeconomic status at Copán (e.g. ethnicity, age, gender) or to other cities characterized by variable topography and informal street networks (Smith, 2007, 2011a). Quantitative measurement will facilitate comparative analysis between cities, and may offer empirical strength to theories of state formation and change that consider social integration as a determining factor (e.g. Blanton and Fargher, 2008; Earle, 1997). Because the spatial layout of urban landscapes influences daily movement and shapes personal interaction, mobility studies help to illuminate social structures and how they may be produced and reproduced.

Acknowledgments - We would like to thank the HUMlab, Umea University, Sweden for their technical support, particularly with the python scripting to automate the least cost analysis during Richards-Rissetto's Digital Humanities Postdoctoral Fellowship. We are grateful to the researchers at the 3D Optical Metrology Unit, Bruno Kessler Foundation, Trento, Italy, for their support. This material is based on work supported by the National Science Foundation under Grant No. 1064648, and the Department of Anthropology and the WCAS IT grant of Northwestern University. The Instituto Hondureño de Antropología e Historia has graciously permitted and supported our work at Copán. We would further like to thank Cynthia Robin, Tom Garrison, Jennifer von Schwerin, Greg Zaro, and two anonymous reviewers for their helpful comments.
Table 3. Round trip (travel time) for Copán's urban core sites.

\begin{tabular}{lcc}
\hline Start & Destination & Round trip (min) \\
\hline Type 4 & Type 4 & $\mathbf{2 2 . 2 4}$ \\
& Type 3 & 23.40 \\
& Type 2 & 27.01 \\
Type 3 & Type 1 & $\mathbf{2 8 . 8 9}$ \\
& Type 4 & 24.80 \\
& Type 3 & 27.71 \\
& Type 2 & 29.32 \\
Type 2 & Type 1 & 31.23 \\
& Type 4 & 24.97 \\
& Type 3 & 28.07 \\
Type 1 & Type 2 & 29.78 \\
& Type 1 & 31.01 \\
& Type 4 & $\mathbf{2 8 . 2 5}$ \\
& Type 3 & 31.07 \\
& Type 2 & 32.49 \\
\hline
\end{tabular}

\section{References}

American Anthropological Association 109th Annual Meeting, 2010. "Circulation" with a Focus on Movement of Signs, Objects, and Bodies, Boundaries, and Encounters, November 17-21, New Orleans, LA.

Anaya Hernandez, A., 2001a. Site Interaction and Political Geography in the Upper Usumacinta Region During the Late Classic: A GIS Approach. In: BAR International Series, vol. 994. Hadrian Books, Oxford. 
Anaya Hernandez, A., 2006. Strategic location and territorial integrity: The role of subsidiary sites in the Classic Maya Kingdoms of the Upper Usumacinta region. Internet Archaeology 19.

Anaya Hernandez, A., 2001b. Site Interaction and Political Geography in the Upper Usumacinta Region During the Late Classic: A GIS Approach. Oxford.

Andrews, E.W., Fash, W.L., 2005. Copán: The History of an Ancient Maya Kingdom, first ed. School of American Research Press, Santa Fe.

Arnauld, M.-C., Manzanilla, L., Smith, M.E., 2012. The Neighborhood as a Social and Spatial Unit in Mesoamerican Cities. University of Arizona Press, Tucson.

Ashmore, W., 1991. Site-planning principles and concepts of directionality among the Ancient Maya. Latin American Antiquity 2, 199-226.

Ashmore, W., Knapp, A.B., 1999. Archaeologies of Landscape: Contemporary Perspectives. Blackwell, Malden, MA.

Aveni, A.F., 2001. Skywatchers. University of Texas Press, Austin.

Bafna, S., 2003. Space syntax: A brief introduction to its logic and analytical techniques. Environment and Behavior 35, 17-29.

Becker, M.J., 1971. The Identification of a Second Plaza Plan at Tikal, Guatemala, and its Implications for Ancient Maya Social Complexity. University of Pennsylvania.

Bell, E.E., Canuto, M.A., Sharer, R.J., 2004. Understanding Early Classic Copán. University of Pennsylvania Museum of Archaeology and Anthropology, Philadelphia, PA.

Bell, T., Lock, G., 2000. Topographic and cultural influence on walking the Ridgeway in later prehistoric times. In: Lock, G. (ed.), Beyond the Map: Archaeology and Spatial Technologies. IOS Press, Amsterdam, pp. 85-100.

Blanton, R.E., Fargher, L., 2008. Collective Action in the Formation of Pre-modern States. Springer, New York, p. 1 v.

Bourdieu, P., 1977. Outline of a Theory of Practice. Cambridge University Press, New York.

Broda, J., 1982. Astronomy, cosmovisión, and ideology in Pre-Hispanic Mesoamerica. In: Aveni, A.F., Urton, G. (eds.), Ethnoastronomy and Archaeoastronomy in the American Tropics, Annals of the New York Academy of Sciences, pp. 81-110.

Carlstein, T., 1982. Time Resources, Society and Ecology. On the Capacity for Human Interaction in Space and Time in Preindustrial Societies. George Allen and Unwin, London.

Chase, D., Chase, A., 1992. Mesoamerican Elites: An Archaeological Assessment. University of Oklahoma Press, Norman and London.

Chase, A.F., Chase, D.Z., 2001. Ancient Maya causeways and site organization at Caracol, Belize. Ancient Mesoamerica 12, 273-281.

Chase, D.Z., Chase, A.F., 2004. Archaeological perspectives on Classic Maya Social Organization from Caracol, Belize. Ancient Mesoamerica 15, 139-147.

Coe, M.D., Van Stone, M., 2005. The Maya, seventh ed. Thames \& Hudson, Ltd., New York.

Dahlin, B.H., Jensen, C.T., Terry, R.E., Wright, D.R., Beach, T., 2007. In search of an Ancient Maya Market. Latin American Antiquity 18, 363-384.

Davis-Salazar, K.L., 2003. Late Classic Maya water management and community organization at Copán, Honduras. Latin American Antiquity 14, 275-299.

De Certeau, M., 1984. The Practice of Everyday Life. University of California Press, Berkeley.

Doyle, J.A., Garrison, T., Houston, S.D., 2012. Watchful realms: Integrating GIS analysis and political history in the Southern Maya Lowlands. Antiquity 68, 792-807.

Earle, T.K., 1997. How Chiefs Come to Power: The Political Economy in Prehistory. Stanford University Press, Stanford, CA.

Fash, B., 2005. Iconographic evidence for water management and social organization at Copán. In: Andrews, E.W., Fash, W.L. (eds.), Copán: The History of an Ancient Kingdom. School of American Research Press, Santa Fe, pp. 103-138.

Fash, W.L., 1983. Maya State Formation: A Case Study and Its Implications (Ph.D. dissertation). Harvard University.

Fash, W.L., 2001. Scribes, Warriors and Kings: The City of Copán and the Ancient Maya, rev. ed. Thames \& Hudson, Ltd., New York.

Fash, W.L., Long, K., 1983. Mapa Arqueológico Del Valle De Copán. In: Baudez, C.F. (ed.), Introducción a La Arqueología De Copán. Instituto Hondureño de Antropología e Historia, Tegucigalpa, Honduras.

Fisher, K.,D., 2009. Placing social interaction: An integrative approach to analyzing past built environments. Journal of Anthropological Archaeology 28, 439-457.

Fletcher, R., 2009. Low-density, agrarian-based urbanism: A comparative view. Insights 2, 2-19.

Fox, J.W., Cook, G.W., Chase, A.F., Chase, D.Z., 1996. Questions of political and economic integration: segmentary versus centralized states among the Ancient Maya. Current Anthropology 37, 795-801.

Giddens, A., 1984. The Constitution of Society: Outline of the Theory of Structuration. University of California Press, Berkeley.

Gillespie, S.D., 2000. Rethinking Ancient Maya Social Organization: Replacing "Lineage" with "House". American Anthropologist $102,467-484$.

Goffman, E., 1983. The interaction order: American Sociological Association, 1982 Presidential Address. American Sociological Review 48, 1-17.

Gonlin, N., 1993. Rural Household Archaeology at Copán, Honduras (Ph.D. dissertation). The Pennsylvania State University.

Harris, T., 2000. Session 2 discussion: moving GIS: exploring movement within prehistoric cultural landscapes using GIS. NATO ASI Series A: Life Sciences 321, 116-123.

Harvey, D., 1996. Justice, Nature, and the Geography of Difference. Blackwell Publishers, Cambridge, Mass.

Herzog, I., Posluschny, A., 2008. Tilt-Slope-dependent least cost path calculations revisited. In: 36th Annual Conference on Computer Applications and Quantitative Methods in Archaeology, Budapest, Hungary.

Hillier, B., 1996. Space is the Machine: A Configurational Theory of Architecture. Cambridge University Press, New York.

Hillier, B., Hanson, J., 1984. The Social Logic of Space. Cambridge University Press, New York.

Hillier, B., Penn, A., Hanson, J., Grajewski, T., Xu, J., 1993. Natural movement-Or, configuration and attraction in urban pedestrian movement. Environment and Planning B: Planning and Design 20, 29-66.

Houston, S., Inomata, T., 2009. The Classic Maya. Cambridge University Press, Cambridge.

Iannone, G., 2002. Annales history and the Ancient Maya State: Some observations on the "dynamic model". American Anthropologist 104, 68-78.

Imhof, E., 1950. Gelände Und Karte, Eilenbach bei Zürich, Rentsch.

Inomata, T., 2004. The spatial mobility of non-elite populations in Classic Maya Society and its political implications. In: Lohse, J.C., Valdez, J., Fred (eds.), Ancient Maya Commoners. University of Texas Press, Austin, pp. 175-196.

Inomata, T., Houston, S.D., 2001. Royal Courts of the Ancient Maya. Westview Press, Boulder, Colorado.

Isendahl, C., Smith, M.E., 2013. Sustainable agrarian urbanism: The low-density cities of the Mayas and Aztecs. Cities 31, 132-143.

Jakobson, R., 1980. The Framework of Language. University of Michigan, Ann Arbor.

Jiang, B., Claramunt, C., 2002. Integration of space syntax into GIS: New perspectives for urban morphology. Transactions in GIS 6, 295-309.

Jiang, B., Gimblett, H.R., 2002. An agent-based approach to environmental and urban systems within Geographic Information Systems. In: Gimblett, H.R. (ed.), Integrating Geographic Information Systems and Agent-based Modeling Techniques for Simulating Social and Ecological Processes. Oxford University Press, Cary, NC, pp. 171-189.

Joyce, R.A., Gillespie, S.D., 2000. Beyond Kinship: Social and Material Reproduction in House Societies. University of Pennsylvania Press, Philadelphia.

Kantner, J., 1997. Ancient roads, modern mapping: Evaluating Chaco Anasazi roadways using GIS technology. Expedition, 49-62. 
Kantner, J., 2004. Geographical approaches for reconstructing past human behavior from prehistoric roadways. In: Goodchild, M.F., Janelle, D.G. (eds.), Spatially Integrated Social Science. Oxford University Press, New York, pp. 323-344.

Kinsella-Shaw, J.M., Shaw, B., Turvey, M.T., 1992. Perceiving 'Walkon-Able' slopes. Ecological Psychology 4, 223-239.

Kintz, E.R., 1983. Class structure in a Classic Maya City. In: Folan, W.J., Kintz, E.R., Fletcher, L.A. (eds.), Coba a Classic Maya Metropolis. Academic Press, New York, pp. 161-177.

Kosiba, S., Bauer, A., 2012. Mapping the political landscape: Toward a GIS analysis of environmental and social difference. Journal of Archaeological Method and Theory, 1-41.

Landau, K., 2013. Proyecto Arqueologico De Los Barrios De Copán, Op 70, Suboperaciones 1-9, Enero-marzo 2012. Report submited to the Instituto Hondureño de Antropología e Historia.

Lawrence, D.L., Low, S.M., 1990. The built environment and spatial form. Annual Review of Anthropology 19, 453-505.

Leventhal, R.M., 1979. Settlement Patterns at Copán, Honduras (Ph.D. dissertation). Harvard University.

Llobera, M., 2000. Understanding movement: A pilot model towards the sociology of movement. In: Lock, G. (ed.), Beyond the Map: Archaeology and Spatial Technologies. IOS Press, Amsterdam.

Llobera, M., Fábrega-Álvarez, P., Parcero-Oubiña, C., 2011. Order in movement: A GIS approach to accessibility. Journal of Archaeological Science 38, 843-851.

Llobera, M., Sluckin, T.J., 2007. Zigzagging: Theoretical insights on climbing strategies. Journal of Theoretical Biology 249, 206-217.

Maca, A.L., 2002. Spatio-temporal Boundaries in Classic Maya Settlement Systems: Copán's Urban Foothills and the Excavations at Group 9j-5 (Ph.D. dissertation). Harvard University.

Martin, S., Grube, N., 2008. Chronicle of the Maya Kings and Queens: Deciphering the Dynasties of the Ancient Maya. Thames \& Hudson, Ltd., New York.

Mathews, J.P., Garber, J.F., 2004. Models of Cosmic order: Physical expression of sacred space among the Ancient Maya. Ancient Mesoamerica 15, 49-59.

Morgan, B.S., 1984. Social geography, spatial structure and social structure. Geo-Journal 9, 301-310.

Munn, N.D., 1996. Excluded spaces: The figure in the Australian Aboriginal landscape. Critical Inquiry 22, 446-465.

Murrieta-Flores, P., 2010. Travelling in a prehistoric landscape: Exploring the influences that shaped human movement. In: Frischer, J., Webb Crawford, J., Koller, D. (eds.), Making History Interactive. Computer Applications and Quantitative Methods in Archaeology (Caa). Proceedings of the 37th International Conference (Williamsburg, Virginia, United States of America 2009), BAR International Series, vol. 2079, pp. 258-276. Oxford.

Murrieta-Flores, P., 2012. Understanding human movement through spatial technologies. The role of natural areas of transit in the Late Prehistory of South-Western Iberia. Trabajos De Prehistoria 69 (1), 103-122. Enero-Junio 2012.

Pandolf, K., Givoni, B., Goldman, R., 1977. Predicting energy expenditure with loads while standing or walking very slowly. Journal of Applied Physiology 43, 577-581.

Parmentier, R.J., 1987. The Sacred Remains: Myth, History, and Polity in Belau. University of Chicago Press.

Parmington, A., 2011. Space and Sculpture in the Classic Maya City. Cambridge University Press, New York.

Peirce, C.S., 1966. Charles S. Peirce, Selected Writings. Dover Publications.

Potter, D.R., King, E.M., 1995. A heterarchical approach to lowland Maya Socioeconomics. In: Ehrenreich, R.M., Crumley, C.L., Levy, J.E. (eds.), Heterarchy and the Analysis of Complex Societies, Archaeological Papers of the American Anthropological Association Number 6.

Pred, A., 1981. Social reproduction and the time-geography of everyday life. Human Geography 63, 5-22.

Proffitt, D.R., Bhalla, M., Gossweiler, R., Midgett, J., 1995. Perceiving geographical slant. Psychonomic Bulletin \& Review 2, 409-428.

Rahn, B., 2005. Cost surface-derived least-cost paths: A case study from Iron Age Orkney. Internet Archaeology 19.
Rapoport, A., 1990. The Meaning of the Built Environment: A Nonverbal Communication Approach. University of Arizon Press, Tucson.

Ratti, C., 2004. Space syntax: Some inconsistencies. Environment and Planning B: Planning and Design 31, 487-499.

Ratti, C., 2005. The lineage of the line: Space syntax parameters from the analysis of urban DEMs. Environment and Planning B: Planning and Design 32, 547-566.

Ratti, C., Baker, N., 2003. Urban infoscapes: New tools to inform city design and planning. ARQ - Architectural Research Quarterly 7, 63-74.

Rice, P.M., 2004. Maya Political Science: Time, Astronomy, and the Cosmos, first ed. University of Texas Press, Austin.

Richards-Rissetto, H.M., 2010. Exploring Social Interaction at the Ancient Maya City of Copán, Honduras: A Multi-scalar Geographic Information Systems (GIS) Analysis of Access and Visibility (Ph.D. dissertation). The University of New Mexico.

Richards-Rissetto, H.M., 2012. Social interaction at the Maya site of Copán, Honduras: A least cost approach to configurational analysis. In: White, D.A., Surface-Evans, S.L. (eds.), Least Cost Analysis of Social Landscapes: Archaeological Case Studies. University of Utah Press, Salt Lake City, pp. 109-127.

Rodrigue, J.-P., Comtois, C., Slack, B., 2009. The Geography of Transport Systems. Routledge, New York.

Sanders, W.T., Webster, D., 1988. The Mesoamerican urban tradition. American Anthropologist 90, 521-546.

Society for American Archaeology. Meeting, 2003. In: Scarborough, V.L., Valdez, F., Dunning, N.P. (eds.), Heterarchy, Political Economy, and the Ancient Maya: The Three Rivers Region of the EastCentral Yucatàn Peninsula. University of Arizona Press, Tucson.

Shaw, L.C., 2012. The Elusive Maya Marketplace: An archaeological consideration of the evidence. Journal of Archaeological Research 20, 117-155.

Shelton, B.D., 2012. Improving pedestrian flow: Agent-based modelling and space syntax within GIS. In: GIScience Proceedings.

Sherrill, K.R., Frakes, B., Schupbach, S., 2010. Travel Time Cost Surface Model: Standard Operating Procedure. Natural Resource Report. Nps/Nrpc/Imd/Nrr-2010/238. Natural Resources Program Center, Fort Collins, Colorado. Published Report-2164894.

Silverstein, M., 1976. Shifters, linguistic categories, and cultural description. In: Basso, K., Selby, H. (eds.), Meaning in Anthropology. School of American Research Advanced Seminar Series, Santa Fe, pp. 11-56.

Smith, M.E., 2007. Form and meaning in the earliest cities: A new approach to ancient urban planning. Journal of Planning History 6, 3-47.

Smith, M.E., 2010. The archaeological study of neighborhoods and districts in ancient cities. Journal of Anthropological Archaeology 29, 137-154.

Smith, M.E., 2011a. Classic Maya settlement clusters as urban neighborhoods: A comparative perspective on low-density urbanism. Journal de la Société des Américanistes 97, 51-73.

Smith, M.E., 2011b. Empirical urban theory for archaeologists. Journal of Archaeological Method and Theory 18, 167-192.

Snead, J.E., Erickson, C.L., Darling, J.A., 2009. Landscapes of Movement: Trails, Paths, and Roads in Anthropological Perspective, first ed. University of Pennsylvania Museum of Archaeology and Anthropology, Philadelphia.

Stanton, T.W., Magnoni, A., 2008. Ruins of the Past: The Use and Perception of Abandoned Structures in the Maya Lowlands. University Press of Colorado, Boulder.

Stark, B.L., Ossa, A., 2007. Ancient settlement, urban gardening, and environment in the Gulf lowlands of Mexico. Latin American Antiquity $18,385-406$.

Stuardo, R.L., 2003. Access patterns in Maya royal precincts. In: Christie, J.J. (ed.), Maya Palaces and Elite Residences. An Interdisciplinary Approach. University of Texas Press, Austin, pp. 184-203.

Taliaferro, M.S., Schriever, B.A., Shackley, M.S., 2010. Obsidian procurement, least cost path analysis, and social interaction in the Mimbres Area of Southwestern New Mexico. Journal of Archaeological Science 37, 536-548. 
Tobler, W., 1993. Three Presentations on Geographical Analysis and Modeling. Technical Report 93-1. National Center for Geographic Information and Analysis. University of California Santa Barbara.

TOPOI, 2011. Workshop: Computational approaches to movement in archaeology. In: Theory, Practice and Interpretation of factors and effects of long term landscape formation and transformation. Freie Universitat, Berlin.

Tourtellot, G., 2004. Excavations at Seibal. In: Peripheral Survey and Excavation, Settlement and Community Patterns, vol. IV. Department of Peten, Guatemala.

Tourtellot, G., Estrada Belli, F., Rose, J.J., Hammond, N., 2003. Late Classic Maya Heterarchy, hierarchy, and landscape at La Milpa, Belize. In: Scarborough, V.L., Valdez Jr., F., Dunning, N. (eds.), Hierarchy, Political Economy and the Ancient Maya: The Three Rivers Region of the East-Central Yucatán Peninsula. The University of Arizona Press, Tucson, pp. 37-51.

Trigger, B.G., 1990. Monumental architecture: A thermodynamic explanation of symbolic behaviour. World Archaeology 22, 119-132.

Van Leusen, M., 2000. Pattern to Process: Methodological Investigations into the Formation and Interpretation of Spatial Patterns in Archaeological Landscapes (PhD dissertation). University of Leiden.

Viel, R.H., 1999. The Pectorals of Altar Q and Structure 11: An interpretation of the political organization at Copan, Honduras. Latin American Antiquity 10, 377-399.

Watanabe, J.M., 2004. Some models in a muddle: Lineage and house in Classic Maya Social Organization. Ancient Mesoamerica 15, 159-166.
Webster, D., 1989. The House of the Bacabs, Copán, Honduras. Dumbarton Oaks Research Library and Collection, Washington, D.C

Webster, D., Gonlin, N., 1988. Household remains of the Humblest Maya. Journal of Field Archaeology 15, 169-190.

Webster, D.L., 1985. Recent settlement survey in the Copán Valley, Honduras. Journal of New World Archaeology 5, 39-51.

Webster, D.L., Freter, A., Gonlin, N., 2000. Copán: The Rise and Fall of an Ancient Maya Kingdom. Harcourt College Publishers, Fort Worth.

Webster, D., 2005. Political ecology, political economy, and the culture history of resource management at Copán. In: Wyllys Andrews, E., Fash, W.L. (eds.), Copán: The History of an Ancient Maya Kingdom. School of American Research, Santa Fe, NM.

Wheatley, D., Gillings, M., 2002. Spatial Technology and Archaeology: The Archaeological Applications of GIS. Taylor \& Francis, London, New York.

White, D.A., Surface-Evans, S.L., 2012. Least Cost Analysis of Social Landscapes: Archaeological Case Studies. University of Utah Press, Salt Lake City.

Willey, G.R., Leventhal, R.M., 1979. Prehistoric settlement at Copán. In: Hammond, N., Willey, G.R. (eds.), Maya Archaeology and Ethnohistory. University of Texas Press, Austin, pp. 75-102.

Zipf, G., 1949. Human Behaviour and the Principle of Least Effort: An Introduction to Human Ecology. Addison-Wesley Press, Inc., Cambridge, MA. 